\title{
Place, Peers, and Play: Children's Belonging in a Preprimary School Setting
}

\author{
Taina Kyrönlampi ${ }^{1} \cdot$ Minna Uitto ${ }^{1} \cdot$ Anna-Maija Puroila ${ }^{1}$
}

Accepted: 25 February 2021 / Published online: 18 March 2021

(c) The Author(s) 2021

\begin{abstract}
This article focuses on children's perspectives of belonging to a place, in this case a Finnish preprimary school setting. This study explores "place-belonging" in photographs originally taken by the children in their preprimary school activities. "Phototelling" was applied as a methodology to link narrative and visual approaches. The research data consist of 13 children's photographs and group discussions, in which the children viewed the photographs with the researcher. The study shows that children's belonging in the preprimary school was intertwined with various elements of the setting, including the people, activities, materiality, and institutional and cultural practices. The findings show how the children can make places of their own and contribute to the setting, how they build their own places, and how these places and associated structures affect the children's actions. Play allows the children to gain familiarity and attachment to places, materials, and peers, hence building a sense of belonging to the preprimary school as a setting. Children's photographs and storytelling activities provide educators with a significant means to support and understand children's perspectives on place and belonging.
\end{abstract}

Keywords Belonging $\cdot$ Children $\cdot$ Narrative $\cdot$ Place $\cdot$ Photographs $\cdot$ Preprimary education

\section{Résumé}

L'article se concentre sur le point de vue des enfants sur l'appartenance à un milieu pré-primaire finlandais en tant que lieu. Cette recherche explore « l'appartenance à un lieu» à partir de photographies prises à l'origine par les enfants dans le cadre de leurs activités à l'école maternelle. Le « photorécit» est appliqué comme méthodologie permettant de relier les approches narratives et visuelles. Les données de

\footnotetext{
The responsible and corresponding authorship is shared equally between Taina Kyrönlampi and
} Minna Uitto.

Taina Kyrönlampi

taina.kyronlampi@oulu.fi

1 Faculty of Education, University of Oulu, Pentti Kaiteran katu 1, 90570 Oulu, Finland 
la recherche consistent en photographies de 13 enfants et en discussions de groupe au cours desquelles les enfants ont examiné les photographies avec le chercheur. La recherche montre que l'appartenance des enfants à l'école maternelle est entrelacée des divers éléments de leur milieu, y compris les personnes, les activités, le matériel ainsi que les pratiques institutionnelles et culturelles. Les résultats démontrent comment les enfants s'approprient les lieux et contribuent au milieu, comment ils construisent leurs propres lieux et comment ces lieux et les structures associées affectent les actions des enfants. Le jeu permet aux enfants de se familiariser et de s'attacher aux lieux, au matériel et aux pairs qui construisent l'appartenance à l'école maternelle comme milieu. Les photographies des enfants et les activités de narration fournissent aux éducateurs un moyen important pour soutenir et comprendre les points de vue des enfants sur le lieu et l'appartenance.

\section{Resumen}

El presente artículo se enfoca en las perspectivas de pertenencia de niños a la escuela preescolar de Finlandia como lugar. Esta investigación explora la pertenencia a un lugar en fotografías originalmente tomadas por niños en sus actividades de preescolar. Se aplicó la metodología de "descripción de fotos" para combinar métodos narrativos y visuales. Los datos de investigación consisten en fotografías de 13 niños y discusiones grupales en las que los niños observan las fotografías con el investigador. La investigación muestra que el sentido de pertenencia de los niños a la escuela preescolar está interconectado con varios elementos contextuales incluyendo personas, actividades, materialidad y prácticas institucionales y culturales. Los hallazgos demuestran la forma en que los niños se apropian de los lugares y contribuyen a su contexto; la forma en la que construyen sus propios lugares; y la forma como esos lugares y las estructuras asociadas a dichos lugares afectan las acciones de los niños. El juego les permite a los niños familiarizarse y apegarse a los lugares, materiales y compañeros que construyen el sentido de pertenencia a la escuela preescolar como ambiente. Las actividades de relato y fotografías de los niños brindan a los educadores un medio importante para apoyar y comprender las perspectivas de los niños en cuanto a lugares y sentido de pertenencia.

\section{Introduction}

Children's perspectives about belonging and 'place' are explored in this research. The place is a Finnish preprimary school setting. The theoretical concept of placebelonging is used in this research, which has also been described as place attachment (Wastell \& Degotardi, 2017). The concepts of belonging and place have received greater research attention in recent years in relation to childhood (Fegter \& Mock, 2019; Green \& Turner, 2017), although less attention has been focused on young children's experiences. The current research addresses this gap and explores children's perspectives on place-belonging and their play environment and the significance that places and material objects can have for children in early education settings to enhance their sense of belonging. 
Research has established the importance of a sense of belonging and attachment for young children for well-being and early learning (May, 2013; Over, 2016). Starting in the child's early years, belonging is understood as a basic need for all human beings. Children seek to create and maintain bonds with adults, peers, places, cultures, spaces and material objects. Such attachments are considered crucial to understanding children's social behavior, evolving identities, and overall well-being (Fegter \& Mock, 2019; Over, 2016). In recent years, there has been increasing interest in exploring children's sense of belonging in the context of institutional education, such as early childhood education. Guo and Dalli (2016) argued that the concept of belonging is now central in early childhood education research, especially in Australia and New Zealand, where a focus on enhancing children's sense of belonging has been embedded in the national curriculum frameworks. In migration studies, belonging has also emerged as a powerful concept to explore how children construct a sense of home and homeland (Cena et al. 2018). Another stream of research on children's belonging has also explored how inclusive education can facilitate children's participation and prevent exclusion (Slee, 2019).

Wastell and Degotardi (2017) identified four emergent themes in the literature on children's belonging (people, place, agency, and inclusion). First, they noted that belonging is mostly explored in terms of human relationships and the formation of children's sense of belonging to others, a social group or community. A second theme relates to place, that is, how children build connections and contribute to the places and environments in which they live. A third theme is described as agency when a child can influence the activities and people with whom they are involved. Finally, they considered the significant theme was the importance of inclusion to a sense of belonging. This current study is connected with the second theme of place and place-belonging within the institutional context of Finnish preprimary education.

The study explores place-belonging through photographs taken by six- and seven-year-old children in their preprimary school activities. 'Photo-telling' was applied as a methodology to link narrative and visual research approaches. Photographs are used as a stimulus for talk and are important participatory method with children, and requiring limited adult intervention, to understand children's everyday experiences across contexts (Cooper, 2017). The research data consisted of photographs taken by 13 children and group discussions, in which the children viewed the photographs with the researcher.

The study is part of a larger international project on children's belonging in educational settings across five countries: Finland, Iceland, the Netherlands, Norway and Sweden. In seeking to capture children's perspectives on placebelonging, we acknowledge that our capacity to understand children's worlds is limited by the very fact that we are adults. For that reason, we assume that the findings reflect the interpretations of both the children and researchers. The study is guided by the following research question: How is place-belonging expressed in children's photo-telling in a preprimary school setting? 


\section{A Relational Approach to Children's Place-Belonging}

Theoretically, the current study draws on a relational approach, in which human beings are seen as inherently connected with, influenced by, and influencing the contexts in which they live (May, 2013; Wastell \& Degotardi, 2017). The concept of place frames the child-context relationship as a multilevel phenomenon. In human geography and in spatially oriented childhood studies, scholars commonly distinguish between the concepts of place and space (e.g., Agnew, 2011; Green $\&$ Turner, 2017). Although space is defined as a specific physical location, place refers to a lived and experienced space imbued with power relations (e.g., Green \& Turner, 2017; Jobb, 2019).

Looking beyond the space-place dichotomy, Agnew (2011) argued for a need to differentiate among three different meanings associated with the concept of place. First, a place can be understood as a location or site where an activity or object is located, for example, a country, a city, or address identifying a physical location (e.g., preprimary school). Second, a place can be understood as a setting where everyday activities and social life occur. In this instance, preprimary schools are not viewed as neutral physical locations but as historically constructed institutions with the specific societal functions of normalizing and civilizing children of a particular age (Bollig \& Millei, 2018). Finally, an individual's sense of place refers to their close identification with a place and with the community that inhabits it (Agnew, 2011). In the present research, children's sense of place emerges when they participate in place-related activities and attach meanings to the places in which they enact their daily lives. This concept of place aligns with the concept of place-belonging, associated with feelings of familiarity and being 'at home' in a place (Antonsich, 2010).

Although we recognize that people can attach different meanings to home depending on their experiences, we utilize 'home' as a metaphor for a place where one experiences familiarity, comfort, emotional attachment, and safety (May, 2013; Yuval-Davis, 2011). As Kirova (2016) put it, "home is intimately tied with one's sense of self; it is where our being finds its genesis and belonging" (p. 2). It is worth noting that along with walls that define boundaries between inner and outer or private and public spaces, place-belonging can also encompass familiar people, material objects, rules, routines, and language used within the space. All of these are significant elements that can be associated with children's place-belonging (Fegter \& Mock, 2019; Green \& Turner, 2017; Kirova, 2016). The concept of place-belonging encompasses children's lived experiences and emotional attachments, for example, in preprimary school contexts as important aspects contributing to children's learning and overall well-being (Fattore et al. 2016).

In this research, a relational approach to children's place-belonging challenges us to consider how children relate to the physical, material, institutional, cultural, and social aspects of the preprimary school as a place. In line with recent studies, we treat children's relationships within the preprimary school context as reciprocal (Bollig \& Millei, 2018; Green \& Turner, 2017). On the one hand, we assume 
that as an institutional educational context, the preprimary school introduces rules, routines, and cultural expectations that may restrict children's opportunities to relate to, utilize, and shape places. On the other hand, we presume that children also play an active role in shaping the preprimary school as a place. Children attach meanings to places that may differ from those meanings assigned to the same place by adult educators (Green \& Turner, 2017).

\section{Photo-telling as a Methodological Approach}

Previous studies have demonstrated the potential of narrative and art-based methods, such as photography, for research with children (Einarsdottir, 2007; Kinnunen \& Puroila, 2016; Leonard \& McKnight, 2015; Oh, 2012). In the current study, phototelling was selected as a methodology linking narrative and visual approaches, enabling us to combine children's photographic and storytelling activities. As in prior research, we assume that photo-telling can reveal issues in children's lives that might otherwise go unnoticed by adults (Einarsdottir, 2007; Kinnunen \& Puroila, 2016; Kyrönlampi et al. 2014). Photo-telling enables us to capturing related feelings about photos and the dialogical interactions that occur among children, photographs, places, and researchers. Other research has shown the dynamic and fragmentary nature of children's storytelling and how children fluently move from one topic to another while photo-telling (Karjalainen et al. 2019; Puroila et al. 2012a). Although we acknowledge that children's authentic experiences ultimately remain inaccessible, photo-telling can provide insights into what they find meaningful in their everyday lives in preprimary school.

\section{Methodology}

\section{Research Context and Participants}

The research context was a Finnish preprimary school. In Finland, all six-year-old children attend preprimary school for one year before they enter primary school (Kopisto et al., 2015). Preprimary schools are located in either schools or in early childhood education settings. Parents must ensure that their children complete this preprimary stage of education. Preprimary teachers are qualified as early childhood education teachers or primary school teachers and must hold a university degree.

The research data were generated in the Spring of 2019 at one preprimary school in an early childhood education setting in northern Finland. The educators in the group included early childhood education teachers, childcare workers, and personal assistants. Of the 23 children in the group (aged 6 and 7 years), 13 children chose to participate in the study. The indoor activities for the children occurred in a locker room, corridor, dining room, play room, and a corner room. The play room was used mainly for free play and rest time. The corner room was situated away from the other rooms and was mostly used for painting and handicraft activities. 
Research ethics were addressed regarding conducting research and working with children; these issues were considered during the research processes for the larger project from which these are derived (Pálmadóttir et al., 2018). Permission to conduct the research was received from the municipality in which the preprimary school was located. Permission was also received from participating children and their parents. Participation was voluntary. On an ongoing basis, the first author, Taina, discussed the research with the participating children. Children's ongoing interest and motivation to participate was observed over time. The children's and educators' names and the location of the preprimary school are not reported to protect participants' identities.

\section{Data Collection}

Taina was responsible for the data collection in one preprimary school setting, and the other authors supported data analysis and writing phases. The preprimary school was one of the Finnish educational settings that participated in the larger international project on children's belonging. At first, Taina talked with the educators about what kind of data would be possible to generate in their preprimary school group. The educators talked about the "Star reporter" activity, in which two children designated as "Star reporters" took digital photographs of their everyday experiences of preprimary school on a weekly basis. Each child was the "Star reporter" for one week, and this activity took place in the preprimary school group for the whole school year. As "Star reporters," the children could move around freely and choose what they photographed. However, they were not allowed to go outdoors with the camera. Taina agreed that relevant research data could be generated within the "Star reporter" activity. Hence, the photographs were not specifically produced for the research purpose but were produced as a part of the everyday practices of the preprimary school.

The educators also suggested that Taina should discuss the photographs with the children in small groups. Before the children attended these discussions (in pairs or groups), the educators discussed the research with the children and introduced Taina. Taina considered it important to get to know the children and to allow them to get to know her prior to the group discussions. For example, she attended morning sessions and played board games with the children. Altogether, there were four group discussions between Taina and the children. Each group discussion was held on a different day. In each group discussion, all photographs that the children of that particular group had taken were discussed. Taina did not limit the storytelling around the photographs during the group discussions. There were no predetermined interview questions, but the group discussions proceeded in a child-centered manner, enabling the children to talk freely about their photographs.

The first group discussion with five children took place in a room with a large table in the middle. The children looked at the photographs on a computer screen and talked about them. Afterward, Taina continued this discussion session with one girl because she had been very quiet during the group process. This is one example of how the researcher attempted to engage children in sensitive ways, as an 
important ethical aspect of research with children (Pálmadóttir et al. 2018; Punch, 2002).

The second group discussion, which involved four children, took place in the dining room using a large smart screen. While the big screen made it easier to look at the photographs, the children's storytelling around their photographs was somewhat disrupted because staff members occasionally walked back and forth through the room. The other two group discussions each involved two children and took place in a quiet room. In each case, Taina sat on a couch with the children as they looked at the photographs on a computer screen and discussed the photos. All discussions were audio-recorded and transcribed by Taina, and the children's photographs were saved on her laptop. The first and second group discussions lasted about $45 \mathrm{~min}$ and the paired discussions lasted about $30 \mathrm{~min}$. In general, the children expressed positive emotions when discussing the photographs and there was a lot of laughter.

The overall research data comprised 352 photographs taken by 13 children. The transcribed group discussions comprised 91 A4 pages (Times New Roman, one and a half-spaced, $12 \mathrm{pt}$ ).

\section{Data Analysis and Interpretation}

The research data were analyzed holistically and inductively without a predetermined conceptual framework. Different phases of the data analysis had some overlap.

First, the authors read the transcriptions of the group discussions while looking at all the photographs to identify what the children were telling us, in general, about their everyday lives at the preprimary school. As the result of the first reading, we identified three distinct but intertwined themes in the data for further exploration about what the children had repeatedly photographed and discussed in the groups. These themes were play, peers, and place.

Second, we revisited the overall research data with a focus on how children's place-belonging is expressed in their photo-telling, while simultaneously referring to theoretical literature on place-belonging (e.g., Agnew, 2011; Green \& Turner, 2017; Wastell \& Degotardi, 2017). This cross-referencing between data and theoretical literature produced a preliminary view of children's place-belonging in the preprimary school and its complexities and dynamics.

Third, we selected one evolving storyline in the children's photo-telling that richly illustrated place-belonging, with the intertwining of play, peers, and place. This storyline emerged in the second group discussion when we noted that particular material items, donut and a chicken, appeared repeatedly in children's photo-telling. To analyze this storyline from the viewpoint of children's place-belonging, we applied Tuval-Maschiach's (2014) model. Tuval-Maschiach (2014) argued that all stories echo three types of places: Immediate intersubjective relationships in which the story is produced; the collective social field addressed in the story; and the metanarratives that facilitate an understanding of the story as a broad system of cultural meaning. 
As applied to this data, this model challenged us to reconsider how the storyline was co-constructed by the children and researchers; how the preprimary school context appeared in the storyline; and how the storyline reflected Finland's broader cultural, societal, and historical context. These findings are discussed in the next section.

\section{Findings}

Three ideas emerged from the data analyses that illustrate how place-belonging may be understood, through photo-telling in the preprimary school, and how placebelonging is associated with children's play, and their interactions with peers and place. This section presents the storyline of the second group discussion with four children and involves a focus on two specific material objects, the donut and the chicken. The data excerpts analyzed in this section show how place-belonging is evident through children's actions and interactions through: (1) use of places and material objects creatively during play; (2) opportunities to move play activities from one place to another and crossing the borders of physical settings; and (3) building their own places and spaces within the possibilities and constraints of the setting.

\section{Creative Use of Material Items and Places during Play}

Our findings in the analyses showed that the children expressed place-belonging during play by creative use of material items and places in the preprimary school setting. This is illustrated by an example involving a donut in the corner room which was a focus in the photographs for the second group discussion which involved four children (Figs. 1 and 2).

Taina: Okay, and here?

Child1: A donut on the floor.

Fig. 1 The donut in the corner room

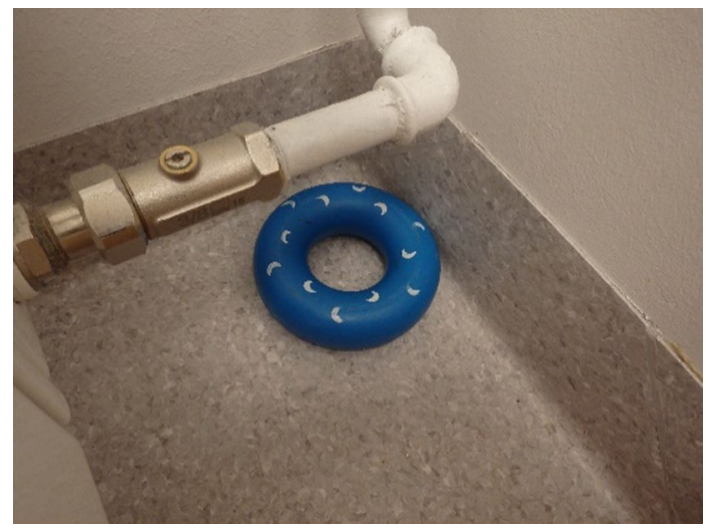


Fig. 2 Clothes pegs in the play room

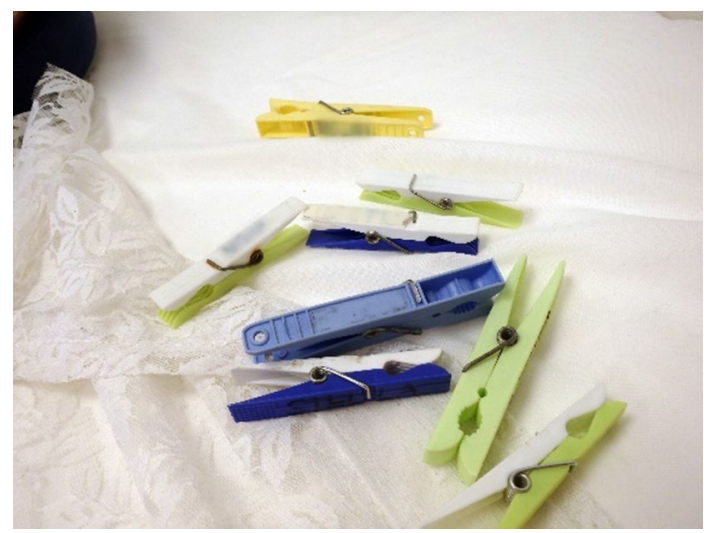

Taina: A donut?

Child 1: It is really a real donut on the floor.

Taina: This is really an eatable donut? Okay, how did it ...

Child 1: No, it's not! (laughs)

Taina: It's not; it's a donut toy. Yes, how did it get there?

Child 1: We played searching for candies, and I found it [the donut] during play. Then... I won't tell more until soon comes... Here, next there will be those clothes pegs. Then it is again about searching for candies and those... We played that the clothes pegs were candies, and that there was one candy chicken, and its swimming ring was that blue one [donut]. We played that in the corner room, and then there were quite a few other candies too, and we played searching for candies...

Child 2: And I was...

Child 1: ... it was the swimming ring in the play.

Child 2: and I was the Easter bunny.

Taina: Okay, yes.

Child 2: So I was hiding these candies. (laughs)

Taina: You hid the candies and then they were searched for?

Child 1: She also had a bunny mask.

Taina: Yes, were you here, in your group's area?

Child 1: No.

Child 2: No.

Child 1: In the corner room.

Taina: In the corner room, yes.

The above example shows how the functions of the material items in the setting were transformed during the children's play. For instance, the meaning of the donut toy changed from something to be eaten into a chicken's swimming ring, and clothes pegs turned into candies that the children were hiding and trying to find. The clothes pegs bear the children's names and are usually used for 
hanging items to dry, for example, gloves in a hot cupboard. However, the children changed the original function of the pegs to suit their play.

In play, everything is possible; indeed, the children's imagination enables them to cross the borders of time, place, and conventional material functions. Laughter flows throughout this joint play, which seems to nourish peer relations, emotional connection, and place-belonging. The children's courage to use the materiality in an active, open, and creative way shows how they enact ownership over the items in the setting, helping to promote place-belonging.

In the example above, the children made the point of saying that the corner room is not traditionally intended for their play. This shows that the children were familiar with the physical layout and names assigned to each place. Moreover, they seemed to be aware of the places' conventional uses and institutional functions. This aligns with prior evidence that children can form their own meaningful relationships with places and that these may differ from what adults anticipate (Green \& Turner, 2017; Joerdens, 2014).

Although this example refers to a preprimary school setting, it can be linked to larger cultural contexts, showing that children's place-belonging has multiple layers. The example reflects Western and Finnish Easter traditions that children find meaningful, in which the Easter Bunny hides candies for children to search for. In their play, the children both maintain these cultural traditions and reproduce them in creative ways. This reminds us how collective events and public figures reflecting the socio-historical context and metanarratives form part of children's storytelling, as Tuval-Maschiach (2014) also suggested.

\section{Crossing Borders of Places during Play}

Besides the creative use of places and material items, the children expressed placebelonging by moving their play flexibly around the setting. Moreover, their play crossed the borders of the physical setting when the children introduced their own toys from home. In the following example, the children's play with the donut and

Fig. 3 The chicken and the donut in the corner room

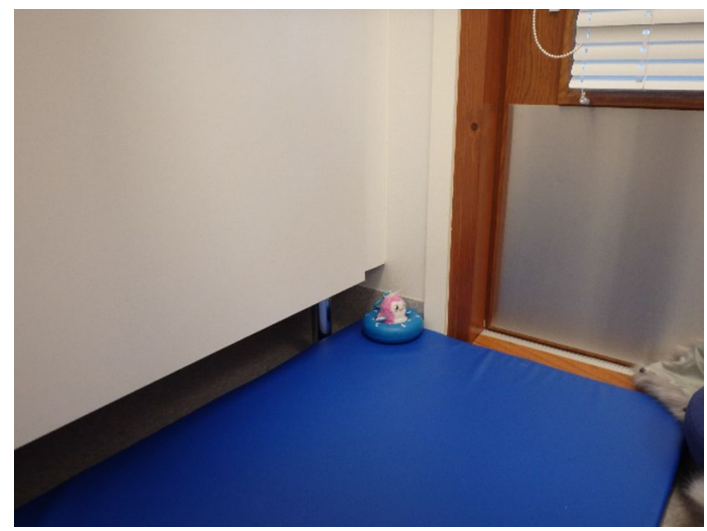


Fig. 4 The chicken with a child in the play room

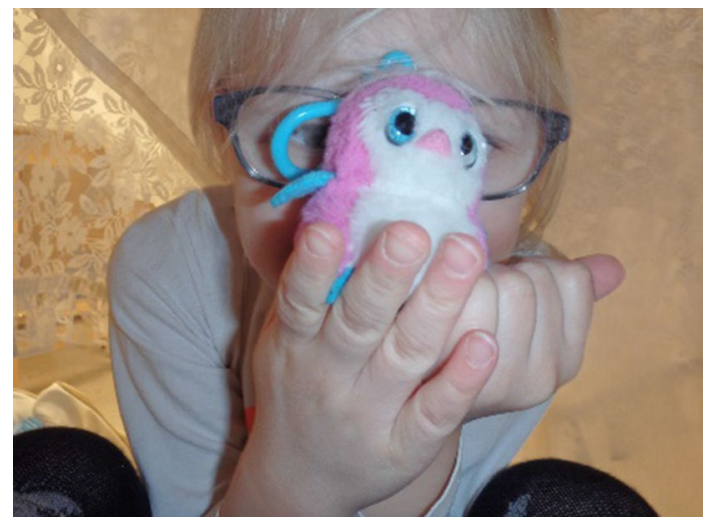

chicken moves within the corner room and then from the corner room to the play room (Figs. 3 and 4).

Child2: There is the chicken!

Taina: There is the chicken! Was it so hungry that it had to go inside the donut and start to eat?

Child1: It was the donut swimming ring.

Taina: Yes, yes.

Child2: Well, that chicken is my soft toy.

Taina: Oh, it's yours-you brought it from home?

Child2: Yes.

Child3: Okay, now turn. [laughs]

Taina: Ohhh. I think this is you, Maria.

Child1: Yes.

Taina: And you have Anna's soft toy there.

[Laughter]

In the example above, the children do not explicitly talk about playing in different places in the setting. However, their photographs capture traces of their play moving from one place to another. Levinas (1996) suggested that people leave traces that can serve as messages that someone has been in that place before. This idea can be applied to our example of children's play, in which the donut and chicken travel inside the setting. The children explore diverse places, enabling them to make the preprimary school setting their own through their joint play with peers. This suggests that moving flexibly from one place to another within the setting is meaningful for children's place-belonging.

The children also contributed to the preprimary school setting by bringing their own toys from home. Joint play with the chicken crossed the border between the private (home) and public (preprimary school). This reflects the cultural and institutional practices in preprimary school settings; previous research has characterized children's own toys in institutional educational settings as a multi-dimensional issue, with one aspect being their significance for children's well-being and emotional security (Puroila et al. 2012b). From the perspective of the current study, it is 


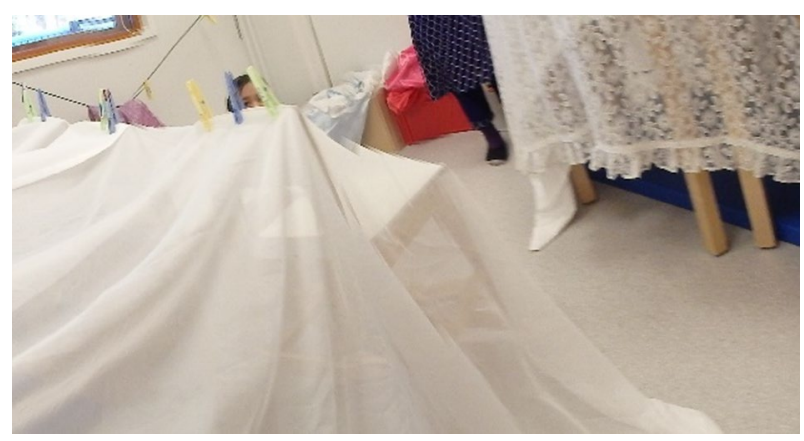

Fig. 5 The hut in the play room

Fig. 6 The chicken in a prison

inside the hut

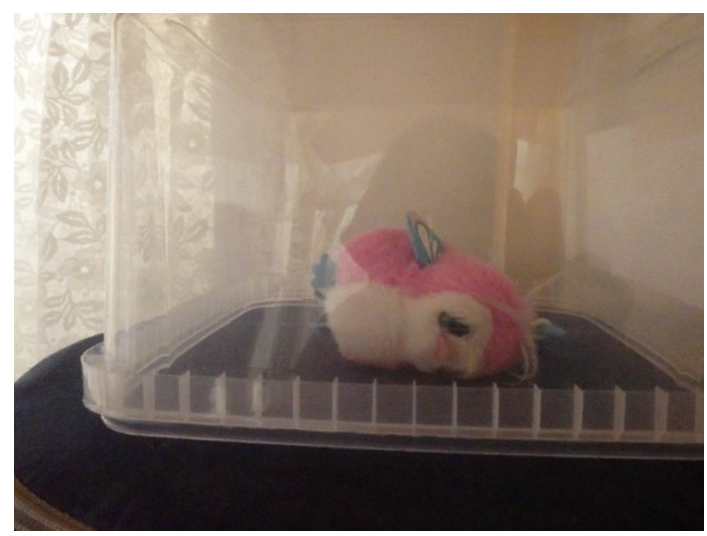

meaningful that familiar material items (such as the chicken) can help the children create place-belonging in an institutional educational setting, which has also been reported in previous research (Kirova, 2016).

\section{Building Places for Play within Everyday Possibilities and Constraints}

The children expressed place-belonging by building their own places in the preprimary school. The cultural and institutional context defines the possibilities and constraints for children to build their own places. In the following example, the children build their own hut (Figs. 5, 6, and 7).

Taina: Yes, okay. What was your play in the hut about?

Child1: That they just capture chickens.

Taina: Capture chickens-yes, okay. Was this chicken already captured?

Child1: Yes [...] It just was captured in this picture. (laughs)

Taina: Oh, you have captured it in this picture?

Child2: I was an eagle in that play. 
Fig. 7 The captured chicken inside the hut

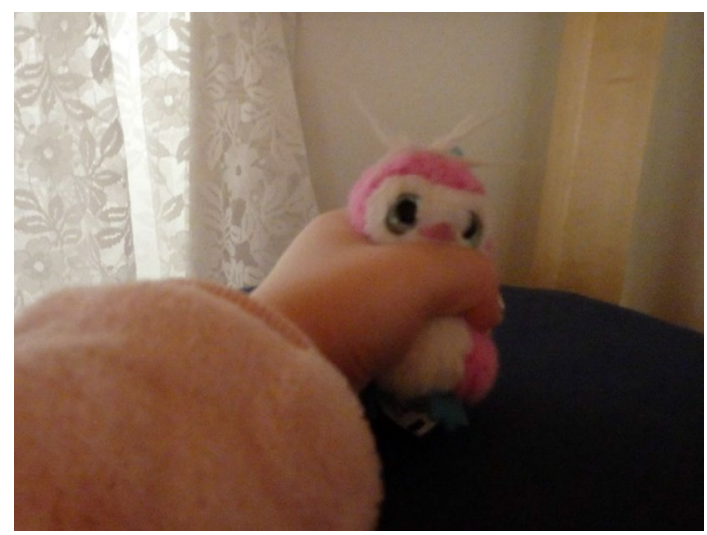

Taina: You were an eagle. What did the eagle do in that play?

Child2: Captured it with these. [...]

Child2: There is Maria hiding.

Child3: There is that little chicken again!

(Laughter)

The above example focuses on how the play moved to the hut that the children built in the play room. Here, the children created different roles, such as prisoner and eagle. The chicken was still at the center of the play an eagle had captured it. The children also created another meaning for a place inside the hut, where a transparent box became a prison for the chicken.

The children did not explicitly mention the adults' involvement in building the hut, but this is clear from the many photographs taken by the children. When building the hut, the children were able to use a variety of materials, such as bed sheets. The example shows how the setting provided the children with a range of resources for use in their joint play, including peers, adults, material items, and places. Together, these also afforded opportunities for the children's placebelonging to evolve.

The children also did not talk about what happened to the hut in the play room. However, elsewhere in the children's photo-telling, they explicitly described how the hut was taken down before their rest time in the play room. This is another reminder of the cultural and institutional practices that frame children's placebelonging, restricting their scope to build their own places. As previous research also noted, the rhythm of children's play in the preprimary school setting must adapt to the rhythm of everyday routines and practices (Juutinen \& Viljamaa, 2016; Sirkko et al. 2019).

Previous research has also suggested that adult educators play a dual role in creating the conditions for children's actions in institutional settings by affording the opportunities for action while maintaining the institutional order (Puroila et al. 2012b; Sirkko et al. 2019). Although the educators remained quite invisible in the storyline discussed here, they undoubtedly influence children's 
opportunities to play creatively in the children's use of materiality and places. Hence, adults also play a dual role in promoting and restricting the conditions for children's place-belonging (Wastell \& Degotardi, 2017).

\section{Discussion}

This article contributes to the research on children's belonging by deepening our understanding of how place-belonging is shaped in an institutional preprimary school setting, which has rarely been addressed in previous studies (Fegter \& Mock, 2019; Green \& Turner, 2017; Wastell \& Degotardi, 2017). Our findings show that as a phenomenon, children's place-belonging is intertwined with various elements of the setting, including people, activities, materiality, and institutional and cultural practices. Moreover, it seems that children's place-belonging is a dynamic and evolving phenomenon rather than a stable state to be achieved (cf. Lindberg, 2014).

The children's relations with the preprimary school setting and place-belonging were expressed in four ways. First, the children make places their own by spending time together in them and by exploring the setting's places and practices. For example, joint play helps children develop peer relations and form an attachment to places (Tuan, 1974). Second, the children contribute to the setting at a profound level by bringing material items and places to life through their imaginations and their actions, jointly reproducing the meanings of places and material items. For example, children tend to transform the meanings of material items according to the needs of their current play (Corsaro, 2003), crossing the borders of time and place. Third, the children could build their own places in the preprimary school setting. For example, the hut appeared as the children's own place both concretely and as a significant place for evolving joint play. Finally, the places and their structures affect the children's opportunities to act. For example, because the day schedule frames children's use of the places, the relations between children and the preprimary school setting as a place are reciprocal, as previous research also has suggested (Bollig \& Millei, 2018; Green \& Turner, 2017).

This article introduces photo-telling as a potential means of acquiring insights into children's place-belonging. During photo-telling, children can return to the events and places they have lived in and photographed. Using this method, photographing and storytelling support each other and both become meaningful. In the current research, the photographs included details and information that the children did not refer to in the group discussions; equally, the photographs would not be understandable without the children's storytelling. However, it is also important to consider what the children did not photograph. For example, there were no photographs about certain daily routines or practices of the preprimary school setting, such as lunches. Still, it is methodologically important that researchers do not make too direct interpretations based on what seems to be lacking in the children's phototelling. For example, although the children did not photograph the educators, their significance when it comes to the children's place-belonging could otherwise be observed. 


\section{Implications}

This article draws attention to the significance that places can have for children: besides belonging, places can enhance children's development, learning, and overall flourishing. For example, it is worth asking whether places invite children to play and explore and in what ways. Do these places provide room for children's imagination and play? While beyond the scope of the current study, it also seems important to explore how nature and the outdoors influence children's place-belonging and how educators might incorporate this dimension into their pedagogical practices.

The findings challenge educators to critically reflect on the possibilities and constraints that institutional, educational places present for children's place-belonging (Lindberg, 2014). The current study also shows the importance for educators to observe and be present in children's play and activities to support the children's place-belonging. Overall, we argue that places need to be problematized and more carefully addressed in planning, implementing, and evaluating pedagogical activities. Therefore, the meaning of places in education and children's place-belonging should be more extensively discussed in both pre- and in-service teacher education.

\section{Limitations and Future Research}

As one limitation of the current study is that as researchers we cannot be sure whether the children were able to share their personal perspectives in the group discussions. It is possible that some participating children did not feel comfortable enough to share their own personal views in the discussions. Moreover, some of the children participating in the group discussions were more talkative than others, sharing strong opinions and not giving room for some other children to participate in the discussion.

Another limitation of the study is that there were no photographs taken by children outdoors. This is a drawback considering that the children in Finnish preprimary schools spend many hours per day outdoors, and the national core curriculum for preprimary education (Finnish National Board of Education, 2016) mentions outdoors as one learning environment. Photographs taken outdoors would have provided insights into what significance outdoor environment may have for children's place-belonging.

As the third limitation of the study can be considered whether photo-telling as a data collection method was able to capture all the aspects of place-belonging. For example, we know that exclusion takes place in groups of children (Juutinen et al., 2018), yet our research data did not provide insights into children's exclusion. It may be that the children with exclusion experiences did not want to participate or talk about those issues in the group discussions.

There is a need to focus in future research on what significance the outdoor environment and nature have for children's place-belonging. Furthermore, it is 
important to approach children's perspectives on place-belonging using different kinds of research methods. Although the current study focused on children's perspectives, it would be likewise interesting to study educators' perspectives on place-belonging in the future-how they build connections and contribute to the preprimary school setting as a place.

\section{Conclusions}

This article has explored children's perspectives on their place-belonging in the everyday life of preprimary school settings. The findings illustrate the significance of places and institutional and cultural practices for children, their peer relations, and their play. Furthermore, the findings show how fluently children can navigate in the social, material, and cultural environment of the setting. In navigating, they come across institutional boundaries and constraints that they must adapt; however, they also test and break those boundaries and constraints.

Photo-telling introduces a holistic approach that provides a potential means to understand children's place-belonging and its shaping in institutional education settings. We suggest that photo-telling is applicable not only in educational research, but also as a pedagogical tool to help educators focus on what children find meaningful in those settings and how children's place-belonging is constructed in their daily lives (Puroila et al. 2012a). When used in this way, photographs and discussions can provide insights into places and events of significance to children that might otherwise remain unknown to educators in everyday institutional life.

Acknowledgments The article was supported by the research project Politics of belonging: Promoting children's inclusion in educational settings across borders, which was funded by NordForsk (Project number 85644). We want to thank Anniina Holappa for editing the photographs so that the children and the places cannot be recognized.

Funding Open access funding provided by University of Oulu including Oulu University Hospital..

Open Access This article is licensed under a Creative Commons Attribution 4.0 International License, which permits use, sharing, adaptation, distribution and reproduction in any medium or format, as long as you give appropriate credit to the original author(s) and the source, provide a link to the Creative Commons licence, and indicate if changes were made. The images or other third party material in this article are included in the article's Creative Commons licence, unless indicated otherwise in a credit line to the material. If material is not included in the article's Creative Commons licence and your intended use is not permitted by statutory regulation or exceeds the permitted use, you will need to obtain permission directly from the copyright holder. To view a copy of this licence, visit http://creativecommons.org/licen ses/by/4.0/.

\section{References}

Agnew, J. (2011). Space and place. In J. Agnew \& D. Livingstone (Eds.), Handbook of geographical knowledge (pp. 316-330). Sage.

Antonsich, M. (2010). Searching for belonging-An analytical framework. Geography Compass, 4(6), 644-659. 
Bollig, S., \& Millei, Z. (2018). Spaces of early childhood: Spatial approaches in research on early childhood education and care. Journal of Pedagogy, 1, 5-20. https://doi.org/10.2478/jped-2018-0001

Cena, E., Heim, D., \& Trandafoiu, R. (2018). Changing places: Children of return migrants in Albania and their quest to belong. Journal of Ethnic and Migration Studies, 44(7), 1156-1176. https://doi. org/10.1080/1369183X.2017.1351336

Cooper, V. L. (2017). Lost in transition: Exploring childhood identity using photo-elicitation. Children's Geographies, 15, 625-637. https://doi.org/10.1080/14733285.2017.1284306

Corsaro, W. (2003). We're friends, right? Inside kid's culture. Joseph Henry Press.

Einarsdottir, J. (2007). Research with children: Methodological and ethical challenges. European Early Childhood Education Research Journal, 15, 197-211. https://doi.org/10.1080/13502930701321477

Fattore, T., Mason, J., \& Watson, E. (2016). Children's understandings of well-being. Towards a child standpoint. Springer.

Fegter, S., \& Mock, C. (2019). Children's emotional geographies of well-being. The cultural constitution of belonging(s) in the context of migration and digital technologies. International Journal of Emotional Education, 11(1), 13-30.

Finnish National Board of Education. (2016). National core curriculum for pre-primary education 2014. Publications 2016: 6. Helsinki: Finnish National Board of Education.

Green, N., \& Turner, M. (2017). Creating children's spaces, children co-creating place. Journal of Childhood Studies, 42(3), 24-40.

Guo, K., \& Dalli, C. (2016). Belonging as a force of agency: An exploration of immigrant children's everyday life in early childhood settings. Global Studies of Childhood, 6(3), 254-267. https://doi.org/ $10.1177 / 2043610616665036$

Jobb, C. (2019). Power, space, and place in early childhood education. Canadian Journal of Early Childhood Education, 44(3), 211-232. https://doi.org/10.29173/cjs29596

Joerdens, S. (2014). 'Belonging means you can go in.' Children`s perspectives and experiences of membership of kindergarten. Australian Journal of Early Childhood, 39(1), 12-21.

Juutinen, J., Puroila, A.-M., \& Johansson, E. (2018). "There is no room for you!" The politics of belonging in children's play situations. In E. Johansson, A. Emilson, \& A.-M. Puroila (Eds.), Values education in early childhood settings: Concepts, approaches and practices (pp. 249-264). Springer.

Juutinen, J., \& Viljamaa, E. (2016). A narrative inquiry about values in a Finnish pre-school: The case of traffic lights. International Journal of Early Childhood, 48, 193-207. https://doi.org/10.1007/ s13158-016-0165-1

Karjalainen, S., Hanhimäki, E., \& Puroila, A.-M. (2019). Dialogues of joy: Shared moments of joy between teachers and children in early childhood education settings. International Journal of Early Childhood, 51(2), 129-143. https://doi.org/10.1007/s13158-019-00244-5

Kinnunen, S., \& Puroila, A.-M. (2016). "If my sister was here"-The narrative in between space in young children's photography process. Childhood, 23(2), 236-254. https://doi.org/10.1177/0975682156 02317

Kirova, A. (2016). Phenomenology of inclusion belonging and language. In M. A. Peters (Ed.), Encyclopedia of educational philosophy and theory (pp. 1-5). Springer Science Business Media.

Kopisto, K., Salo, L., Lipponen, L., \& Krokfors, L. (2015). Transformations and tensions in Finnish early childhood education and care. In L. R. Kroll \& D. R. Meier (Eds.), Educational change in international early childhood contexts Crossing borders of reflection (pp. 141-154). Sage.

Kyrönlampi, T., Uusiautti, S., \& Määttä, K. (2014). What is after-school childhood like? Children's descriptions of their daily rhythms. International Journal of Research Studies in Education, 4, 1-25. https://doi.org/10.5861/ijrse.2014.704

Leonard, M., \& McKnight, M. (2015). Look and tell: Using photo-elicitation methods with teenagers. Children's Geographies, 13(6), 629-642. https://doi.org/10.1080/14733285.2014.887812

Levinas, E. (1996). Etiikka ja äärettömyys. Keskusteluja Philip Nemon kanssa. Gaudeamus.

Lindberg, P. (2014). In search of affordances and visual quality Interpreting environments of children aged under three in seven Finnish day-care centres. University of Oulu.

May, V. (2013). Connecting self to society. Belonging in a changing world. Palgrave Macmillan.

Oh, S.-A. (2012). Photofriend: Creating visual ethnography with refugee children. AREA: Royal Geographical Society, 4(2), 282-288. https://doi.org/10.1111/j.1475-4762.2012.01111.x

Over, H. (2016). The origins of belonging: Social motivation in infants and young children. Philosophical Transaction Royal Society B, 371(20150072), 1-8. https://doi.org/10.1098/rstb.2015.0072 
Pálmadóttir, H., Juutinen, J., \& Viljamaa, E. (2018). Sharing horizons: Methodological and ethical reflections on video-observations. In E. Johansson, A. Emilson, \& A.-M. Puroila (Eds.), Values education in early childhood settings: Concepts, approaches and practices (pp. 129-144). Springer.

Puroila, A.-M., Estola, E., \& Syrjälä, L. (2012a). Does Santa exist? Children's everyday narratives as dynamic meeting places in a day care centre context. Early Child Development and Care, 182(2), 191-206. https://doi.org/10.1080/03004430.2010.549942

Puroila, A.-M., Estola, E., \& Syrjälä, L. (2012b). Having, loving, being: Children's narrated well-being in Finnish day care centres. Early Child Development and Care, 182(3-4), 345-362.

Punch, S. (2002). Research with children: The same or different from research with adults? Childhood, 9(3), 321-341. https://doi.org/10.1177/0907568202009003005

Sirkko, R., Kyrönlampi, T., \& Puroila, A.-M. (2019). Children's agency: Opportunities and constraints. International Journal of Early Childhood, 51, 283-300. https://doi.org/10.1007/ s13158-019-00252-5

Slee, R. (2019). Belonging in an age of exclusion. International Journal of Inclusive Education, 23(9), 909-922. https://doi.org/10.1080/13603116.2019.1602366

Tuan, Y.-F. (1974). Topophilia A study of environmental perception, attitudes and values. New York: Columbia University Press.

Tuval-Maschiach, R. (2014). Life-stories in context: Using the three-sphere context model to analyse Amos's narrative. Narrative Works: Issues, Investigations \& Interventions, 4(1), 125-145.

Wastell, S., \& Degotardi, S. (2017). 'I belong here: I been coming a big time': An exploration of belonging that includes the voice of children. Australian Journal of Early Childhood Education, 42(4), 38-46. https://doi.org/10.23965/AJEC.42.4.05

Yuval-Davis, N. (2011). The politics of belonging. Intersectional contestations. Sage.

Publisher's Note Springer Nature remains neutral with regard to jurisdictional claims in published maps and institutional affiliations. 